\title{
Le Petit Machiavellian Prince: Effects of latent toxoplasmosis on political beliefs and values
}

\author{
Robin Kopecky ${ }^{1}$, Lenka Př́íplatová ${ }^{1}$, Silvia Boschetti ${ }^{1}$, Konrad Talmont-Kaminski ${ }^{1}$, \\ and Jaroslav Flegr ${ }^{2}$, \\ $1 \quad$ Institute of Philosophy of the Czech Academy of Sciences, Prague, Czechia \\ 2 Laboratory of Evolutionary Biology, Department of Philosophy and History of Sciences, \\ Faculty of Science, Charles University, Prague, Czechia \\ * $\quad$ Correspondence: flegr@cesnet.cz, Vinicna 7, 12800 Prague 2, Czechia
}

\begin{abstract}
:
Humans infected by Toxoplasma gondii express no specific symptoms but manifest higher incidence of many diseases, disorders and differences in personality and behaviour. The aim of this study was to compare the political beliefs and values of Toxoplasma-infected and Toxoplasma-free participants. We measured beliefs and values of 2315 responders via an online survey (477 Toxoplasma-infected) using the Political Beliefs and Values Inventory (PI34). This study showed Toxoplasma-infected and Toxoplasma-free participants of our cross-sectional study differed in three of four factors of PI34, scoring higher in Tribalism and lower in Cultural liberalism and Anti-Authoritarianism. We found sex differences in political beliefs associated with Toxoplasma infection. Infected women scored higher in tribalism and lower in cultural liberalism, compared with the Toxoplasma-free control group, while infected men scored higher in economic equity. These results fit with sexual differences in behaviour and attitude observed after toxoplasmosis infection. Controlling for the effect of worse physical health and mental health had little impact, suggesting that impaired health did not cause these changes. Rather than adaptation to prevalence of parasites, as suggested by parasite-stress theory, the differences might be side-effects of long-term mild inflammatory re-action, although definitive conclusions cannot be reached due to lack of relevant literature.
\end{abstract}

Keywords: Toxoplasma gondii, manipulation hypothesis, political beliefs, stress, infectious diseases, parasite threat, pathogen avoidance

\section{Introduction}

Toxoplasma gondii, the parasitic protozoon of cats, infects about one-third of the hu-man population in both developed and developing countries [1]. Infected humans express no specific symptoms of the life-long infection; however, they differ from non-infected subjects by a higher incidence of many diseases and disorders [2,3] and also by specific changes in personality [4-6] and behaviour [7,8]. These behavioural differences are mostly considered to be products or by-products of the manipulative activity of Toxoplasma aimed to increase the chance of transmitting from the infected intermediate host, which can be any warm-blooded animal, to its definitive host, a cat [9]. It was suggested recently [10-12], that a large part of the observed toxoplasmosis-associated changes are 
not the products of the manipulative activity of Toxoplasma, but a result of mild chronic stress associated with long-term parasitic infection and resulting health problems. It is known that many toxoplasmosis-associated changes go in opposite directions in the infected men and women [13], and also that men and women cope with stress in diametrically opposed ways [14,15]. The stress-coping hypothesis suggests that many toxoplasmosis-associated changes, e.g., higher extroversion in infected women and lower in men, or lower suspiciousness of infected women and higher in suspiciousness of infected men (all in comparison to non-infected peers) can be interpreted as gender-dependent stress coping reaction.

Additionally, the immune response to chronic stress due to parasite infection may elicit a different immune response in the two sexes and lead to different behavioural changes. Research focused on the role of cytokines in the inflammatory process of the CNS showed the presence of a difference between males and females [16,17]. The increment of cytokines during toxoplasmosis infection can affect the dopaminergic function [18] and provoke the behavioural change [19]. Indeed, many of the behavioural changes associated with toxoplasmosis are correlated with the dopaminergic system in humans and in rats $[20,21]$. Therefore, the behavioural differences observed in infected men and women can be a consequence of differences in the immune response system, related to the production of cytokines and the function of the dopaminergic system.

Among the traits affected by toxoplasmosis are also such that could affect the political beliefs of infected subjects. For example, infected men have lower superego strength, i.e., the tendency to disregard rules of society, while the opposite tendency was observed in infected women [21]. Both infected men and women have lower conscientiousness [4], lower generosity [10] and have lower novelty-seeking $[22,23]$. Men express lower and women higher altruism in the dictatorship game [10]. Infected subjects express higher entrepreneurship activity and have a higher tendency for risky behaviour [24], which might explain a higher risk of traffic accidents in the infected subjects [25,26]. Toxoplasma-infected women have also higher aggression [27] and self-aggression [28,29].

Although certain effects of infection by a parasitic disease on political views ought to be expected based on the research summarized above, to our knowledge, no relation of toxoplasmosis (or other parasitic disease) and political beliefs and values has been re-ported to date. Moreover, studies focused on possible causal connection between infectious diseases (except for toxoplasmosis) and changes in personality profiles are also few and far between and focused mainly on diseases causing profound changes in brain, e.g., AIDS [30] or neurocysticercosis [31].

Regarding the connection between parasite stress and political views, there exists ex-tensive literature describing changes in traits that differ with varied geographical parasite stress levels. All published studies, however, are population-based studies, searching for the difference between populations exposed to different intensity of the parasite stress. While it is possible to consider our data in the context of this parasite-stress theory and it will be done so in the Discussion, this study primarily focuses on association between Toxoplasma status and political beliefs on an individual level. For this purpose, we measured political beliefs and values of 2315 respondents of an internet survey (477 Toxoplasma-infected) using the Political Beliefs and Values Inventory (PI34). To test the hypothesis that the observed changes in three of the factor (Tribalism, Cultural Liberalism, and Antiauthoritarianism), but not the fourth (Economic Equity), are related to stress-coping strategies of 
men and women, we ran the analyses separately for each sex and to find out whether the observed differences are mediated by impaired health of the infected subjects we analysed also a complex model controlling not only for age, sex, size of place of residence, and level of education but also for physical health and mental health.

\section{Results}

The final data set of 2315 respondents, consisted of 467 men (mean age 35.54, s.d. 12.8) and 1848 women (mean age 35.95, s.d. 11.5); the difference in age was not significant $(\mathrm{t}=-0.69, \mathrm{df} .=2313, \mathrm{p}=$ 0.493). In men, 90 men (mean age 35.54, s.d. 12.9) were infected with Toxoplasma and 377 (mean age 35.53, s.d. 12.4) were Toxoplasma-free; again, the difference in age was not significant $(\mathrm{t}=-0.69$, df. $=2313, \mathrm{p}=0.493$ ). In contrast, the difference in age between 518 Toxoplasma-infected women (mean age 38.39, s.d.12.8) and 1330 Toxo-plasma-free women (mean age 35.01, s.d.11.2) was highly significant $(\mathrm{t}=-5.72, \mathrm{df} .=1846, \mathrm{p} \ll 0.0001)$. Prevalence of toxoplasmosis was lower in men $(19.27 \%)$ than in women (28.03\%) (Chi2 = 14.8, $\mathrm{p}=0.0001)$. Prevalence of toxoplasmosis decreased with size of place of residence from $32.9 \%$ in smallest villages to $20.9 \%$ in the cities over 500,000 inhabitants (Partial Tau controlled for age and sex $=-0.070, p<0.0001$ ). No association was observed

Figure 1. Association of toxoplasmosis and sex on health. The vertical bars show 95\% C.I., the mean values computed for covariates (age and size of place of living) at their means.

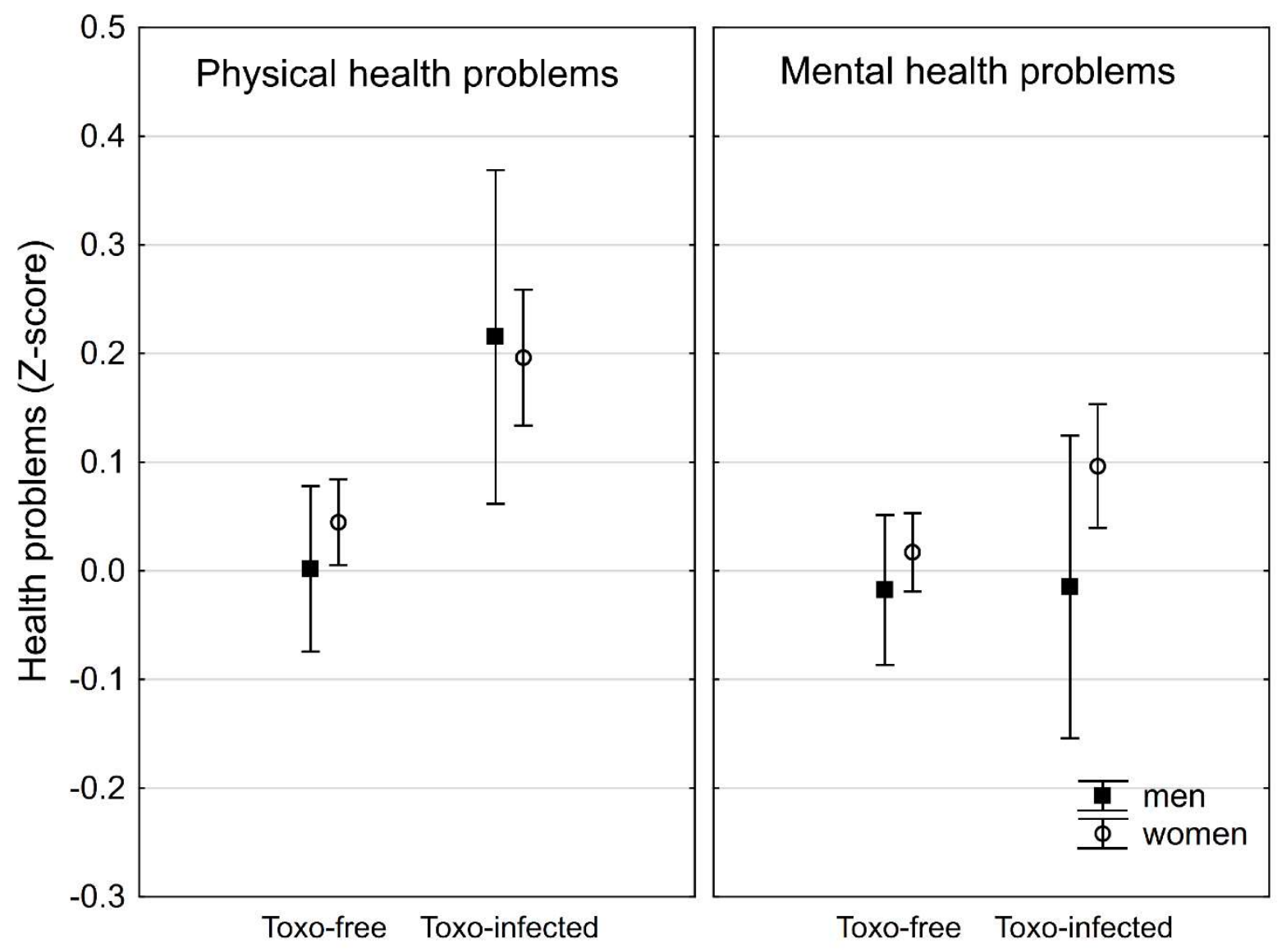


between toxoplasmosis and education (Partial Tau controlled for age and sex $=-0.013, p=0.368$ ), however, the absence of the association in the whole population was caused by the existence of positive association between toxoplasmosis and achieved level of education in men (Partial Tau controlled for age and sex $=0.083, \mathrm{p}=0.007$ ) and negative association between the toxoplasmosis and achieved level of education in women (partial Tau con-trolled for age and sex $=-0.037, p=0.017$ ).

Toxoplasma-infected women expressed worse mental and physical health, and Toxo-plasma-infected men worse physical health than their Toxoplasma-free peers (Figure 1). MANCOVA computed with the physical and mental health problems as the dependent variables, toxoplasmosis, sex, and sextoxoplasmosis interaction as the factors, and age and size of place of living as covariates showed significant effects of age $(\mathrm{F} 2,1843=70.02, \mathrm{p}<<0.0001$, partial eta2 $=0.07)$ and toxoplasmosis $(\mathrm{F} 2,1843=7.34, \mathrm{p}=0.0007$, partial eta2 $=0.008)$. Results of corresponding ANCOVA analyses computed separately for physical and mental health problems and men, women, and men and women together are shown in Table 1.

Factor analysis performed on data from the Political Inventory revealed four factors with an eigenvalue higher than 1.0. According to loading of these factors by particular questions of the inventory (Tab. 2), it was possible to identify these factors as Tribalism (11.5\% of variability), Economic equity preference (7.8\% of variability), Cultural liberalism (5.1\% of variability), and Antiauthoritarianism (3.0\% of variability). We computed values of these four variables for each respondent as scores in particular factors.

Table 1. The associations between physical and mental health and toxoplasmosis. The table shows the effects of toxoplasmosis, age, and size of place of living computed by ANCOVA for all subjects,

men, and women.

PHYSICAL HEALTH PROBLEMS MENTAL HEALTH PROBLEMS

\begin{tabular}{l|llllll} 
ALL & $\mathbf{F 1 , 1 8 4 6}$ & $\mathbf{p}$ & Partial eta2 & $\mathbf{F 1 , 2 3 0 1}$ & $\mathbf{p}$ & Partial eta2 \\
INTERCEPT & 24.86 & 0.0000 & 0.013 & 10.89 & 0.0010 & 0.005 \\
AGE & 64.94 & 0.0000 & 0.034 & 35.39 & 0.0000 & 0.015 \\
SIZE OF PLACE & 3.50 & 0.0615 & 0.002 & 0.51 & 0.4749 & 0.000 \\
OF LIVING & & & & & & \\
TOXOPLASMOSIS & 22.11 & 0.0000 & 0.012 & 6.64 & 0.0100 & 0.003 \\
MEN & $\mathbf{F 1 , 3 5 3}$ & $\mathbf{p}$ & Partial eta2 & $\mathbf{F 1 , 4 6 2}$ & $\mathbf{p}$ & Partial eta2 \\
INTERCEPT & 9.99 & 0.0017 & 0.028 & 0.00 & 0.9539 & 0.000 \\
AGE & 23.44 & 0.0000 & 0.062 & 6.75 & 0.0097 & 0.014 \\
SIZE OF PLACE & 2.16 & 0.1423 & 0.006 & 2.10 & 0.1484 & 0.005 \\
OF LIVING & & & & & & \\
TOXOPLASMOSIS & 5.95 & 0.0153 & 0.017 & 0.03 & 0.8681 & 0.000 \\
WOMEN & $\mathbf{F 1 , 1 4 8 9}$ & $\mathbf{p}$ & $\mathbf{P a r t i a l ~ e t a 2}$ & $\mathbf{F 1 , 1 8 3 5}$ & $\mathbf{p}$ & Partial eta2 \\
INTERCEPT & 15.88 & 0.0001 & 0.011 & 11.67 & 0.0006 & 0.006 \\
AGE & 43.40 & 0.0000 & 0.028 & 28.36 & 0.0000 & 0.015 \\
SIZE OF PLACE & 2.15 & 0.1423 & 0.001 & 0.17 & 0.6824 & 0.000 \\
OF LIVING & & & & & & \\
TOXOPLASMOSIS & 16.19 & 0.0001 & 0.011 & 6.32 & 0.0120 & 0.003
\end{tabular}


Table 2. Loadings of four factors identified by factor analysis of 34 questions of the Political Inventory

\begin{tabular}{|c|c|c|c|c|}
\hline & Tribalism & $\begin{array}{l}\text { Economic } \\
\text { equity }\end{array}$ & $\begin{array}{l}\text { Cultural } \\
\text { liberalism }\end{array}$ & $\begin{array}{l}\text { Anti- } \\
\text { authoritarianism }\end{array}$ \\
\hline $\begin{array}{l}\text { reduce income } \\
\text { differences }\end{array}$ & -0.029 & 0.768 & -0.053 & 0.000 \\
\hline $\begin{array}{l}\text { same sex } \\
\text { together }\end{array}$ & -0.255 & -0.036 & 0.504 & 0.113 \\
\hline right to protest & -0.062 & 0.004 & 0.082 & 0.466 \\
\hline $\begin{array}{l}\text { to regulate } \\
\text { corporation }\end{array}$ & -0.072 & 0.289 & 0.057 & -0.063 \\
\hline $\begin{array}{l}\text { good for corp. Is } \\
\text { good for society }\end{array}$ & 0.190 & -0.156 & -0.008 & -0.069 \\
\hline $\begin{array}{l}\text { minimize } \\
\text { differences in } \\
\text { status }\end{array}$ & -0.007 & 0.800 & -0.075 & 0.001 \\
\hline pornography & -0.051 & -0.058 & 0.351 & 0.302 \\
\hline $\begin{array}{l}\text { citizens over } \\
\text { foreigners }\end{array}$ & 0.674 & 0.049 & -0.086 & 0.099 \\
\hline $\begin{array}{l}\text { minorities are } \\
\text { threat }\end{array}$ & 0.715 & 0.056 & -0.128 & 0.004 \\
\hline $\begin{array}{l}\text { class not } \\
\text { nationality }\end{array}$ & -0.228 & 0.172 & 0.121 & 0.018 \\
\hline $\begin{array}{l}\text { rich are taxed } \\
\text { too much }\end{array}$ & 0.108 & -0.416 & 0.032 & 0.047 \\
\hline $\begin{array}{l}\text { religion not to } \\
\text { be disgraced }\end{array}$ & -0.088 & 0.128 & -0.060 & -0.428 \\
\hline $\begin{array}{l}\text { decriminalize } \\
\text { marihuana }\end{array}$ & -0.108 & 0.006 & 0.186 & 0.264 \\
\hline euthanasia & 0.170 & 0.037 & 0.644 & 0.149 \\
\hline $\begin{array}{l}\text { parents can } \\
\text { spank children }\end{array}$ & 0.388 & -0.100 & 0.019 & 0.064 \\
\hline $\begin{array}{l}\text { there are no } \\
\text { barbarians }\end{array}$ & -0.309 & 0.131 & 0.123 & -0.130 \\
\hline $\begin{array}{l}\text { cancel borders } \\
\text { and nations }\end{array}$ & -0.466 & 0.194 & 0.094 & 0.098 \\
\hline $\begin{array}{l}\text { immigrants } \\
\text { won't } \\
\text { assimilate }\end{array}$ & 0.624 & 0.021 & -0.128 & 0.034 \\
\hline $\begin{array}{l}\text { no work no } \\
\text { social benefits }\end{array}$ & 0.448 & -0.137 & 0.075 & -0.042 \\
\hline $\begin{array}{l}\text { to each } \\
\text { according } \\
\text { needs }\end{array}$ & 0.056 & 0.363 & 0.046 & -0.081 \\
\hline $\begin{array}{l}\text { mothers stay at } \\
\text { home }\end{array}$ & 0.380 & 0.071 & -0.305 & -0.072 \\
\hline free speech & 0.043 & -0.097 & 0.080 & 0.554 \\
\hline no abortion & 0.065 & 0.066 & -0.601 & -0.101 \\
\hline
\end{tabular}


6 / 19 Le Petit Machiavellian Prince: Effects of latent toxoplasmosis on political beliefs and values

\begin{tabular}{|c|c|c|c|c|}
\hline $\begin{array}{l}\text { respect } \\
\text { authority }\end{array}$ & 0.368 & -0.013 & 0.002 & -0.242 \\
\hline proud of history & 0.267 & -0.030 & -0.100 & -0.032 \\
\hline poor but equal & 0.108 & 0.664 & -0.082 & -0.104 \\
\hline $\begin{array}{l}\text { free market is } \\
\text { free society }\end{array}$ & 0.110 & -0.367 & 0.105 & 0.223 \\
\hline home-school & -0.184 & -0.030 & -0.079 & 0.209 \\
\hline $\begin{array}{l}\text { no to internet } \\
\text { censorship }\end{array}$ & 0.025 & -0.067 & 0.096 & 0.453 \\
\hline $\begin{array}{l}\text { an eye for an } \\
\text { eye }\end{array}$ & 0.610 & 0.074 & 0.164 & -0.008 \\
\hline $\begin{array}{l}\text { my life for the } \\
\text { nation }\end{array}$ & 0.244 & -0.037 & -0.180 & 0.047 \\
\hline $\begin{array}{l}\text { capital } \\
\text { punishment }\end{array}$ & 0.635 & 0.062 & 0.228 & -0.122 \\
\hline right to firearm & 0.356 & -0.178 & -0.034 & 0.360 \\
\hline $\begin{array}{l}\text { deport foreign } \\
\text { criminals }\end{array}$ & 0.412 & 0.023 & -0.048 & 0.049 \\
\hline
\end{tabular}

To disclose the effect of Toxoplasma infection on political beliefs, we computed the as-sociations of the toxoplasmosis with Tribalism, economic equity preference, Cultural liberalism, and Antiauthoritarianism using partial Kendall correlation controlled to age, sex, and size of place of residence. The results showed that being Toxoplasma-infected correlated positively with Tribalism and negatively with Cultural liberalism, and Anti-authoritarianism, see table 3. All three associations retain statistical significance after the correction for multiple tests. Table 3 also shows the results of the same analyses per-formed separately for men and women. The most conspicuous sexual differences were the absence of the positive association of toxoplasmosis with Tribalism in men here the partial Tau was even negative, $-0.014, p=0.760$ in men vs. $0.040, p=0.009$ in women, and presence of the positive association with the preference for economic equity in men $0.064, p=0.040$ but not in women Tau $=0.010, \mathrm{p}=0.526$, see Figure 2 .

Toxoplasmosis had a strong association with human health and the size of the place of residence. At the same time, political beliefs had a strong association with health, size of place of residence, and achieved level of education (Tab. 3, left part). It could be therefore speculated that the association between toxoplasmosis and health is just the side effects of the associations of toxoplasmosis with these confounding variables. To test this possibility, we repeated the partial Kendall analyses, this time controlled not only for sex, age, and size of place of residence but also for physical and mental health and achieved level of education. The results were nearly identical as those obtained with the simpler model (Tab. 3, right part). Therefore, the effect of toxoplasmosis on political beliefs is not mediated by the effect of toxoplasmosis on health or education. 
Table 3. Correlation of political beliefs with toxoplasmosis and potential confounding variables. The left half of the table shows partial Kendall Tau controlled for age, sex, size of place of residence, and the right half Tau controlled for age, sex, size of place of residence, physical health, mental health, and achieved education level. A variable that was used as the dependent variable) was removed from the list of covariates to be controlled for. Statistically significant results were printed in bold.

\begin{tabular}{|c|c|c|c|c|c|c|c|c|}
\hline & Tribalism & $\begin{array}{l}\text { Econom. } \\
\text { Equity }\end{array}$ & $\begin{array}{l}\text { Cult. } \\
\text { Lib. }\end{array}$ & $\begin{array}{l}\text { Anti- } \\
\text { author. }\end{array}$ & Tribalism & $\begin{array}{l}\text { Econom. } \\
\text { Equity }\end{array}$ & $\begin{array}{l}\text { Cult. } \\
\text { Lib. }\end{array}$ & $\begin{array}{l}\text { Anti- } \\
\text { author. }\end{array}$ \\
\hline & ALL & & & & ALL & & & \\
\hline Toxo & 0.029 & 0.020 & -0.042 & -0.034 & 0.029 & 0.020 & -0.042 & -0.034 \\
\hline Age & 0.024 & -0.039 & -0.104 & -0.033 & 0.024 & -0.039 & -0.104 & -0.033 \\
\hline Sex & 0.003 & 0.032 & 0.062 & -0.234 & 0.003 & 0.032 & 0.062 & -0.234 \\
\hline Living & -0.089 & -0.054 & 0.063 & 0.027 & -0.089 & -0.054 & 0.063 & 0.027 \\
\hline Education & -0.098 & -0.080 & 0.023 & -0.008 & -0.098 & -0.080 & 0.023 & -0.008 \\
\hline $\begin{array}{l}\text { Physical } \\
\text { health }\end{array}$ & 0.043 & 0.027 & -0.002 & -0.041 & 0.043 & 0.027 & -0.002 & -0.041 \\
\hline \multirow{2}{*}{$\begin{array}{l}\text { Mental } \\
\text { health }\end{array}$} & -0.001 & 0.070 & 0.031 & 0.025 & -0.001 & 0.070 & 0.031 & 0.025 \\
\hline & WOMEN & & & & WOMEN & & & \\
\hline Toxo & 0.040 & 0.010 & -0.038 & -0.030 & 0.040 & 0.010 & -0.038 & -0.030 \\
\hline Age & 0.022 & -0.034 & -0.105 & -0.027 & 0.022 & -0.034 & -0.105 & -0.027 \\
\hline Living & -0.092 & -0.053 & 0.055 & 0.017 & -0.092 & -0.053 & 0.055 & 0.017 \\
\hline Education & -0.124 & -0.084 & 0.025 & -0.020 & -0.124 & -0.084 & 0.025 & -0.020 \\
\hline $\begin{array}{l}\text { Physical } \\
\text { health }\end{array}$ & 0.058 & 0.036 & -0.003 & -0.043 & 0.058 & 0.036 & -0.003 & -0.043 \\
\hline \multirow{2}{*}{$\begin{array}{l}\text { Mental } \\
\text { health }\end{array}$} & 0.013 & 0.073 & 0.056 & 0.001 & 0.013 & 0.073 & 0.056 & 0.001 \\
\hline & MEN & & & & MEN & & & \\
\hline Toxo & -0.015 & 0.064 & -0.060 & -0.055 & -0.015 & 0.064 & -0.060 & -0.055 \\
\hline Age & 0.022 & -0.045 & -0.079 & -0.037 & 0.022 & -0.045 & -0.079 & -0.037 \\
\hline Living & -0.080 & -0.050 & 0.073 & 0.041 & -0.073 & -0.043 & 0.071 & 0.040 \\
\hline Education & -0.061 & -0.074 & 0.020 & 0.012 & -0.062 & -0.072 & 0.020 & 0.014 \\
\hline $\begin{array}{l}\text { Physical } \\
\text { health }\end{array}$ & 0.022 & 0.015 & -0.001 & -0.041 & 0.021 & 0.016 & -0.002 & -0.079 \\
\hline $\begin{array}{l}\text { Mental } \\
\text { health }\end{array}$ & -0.024 & 0.066 & -0.008 & 0.060 & -0.028 & 0.061 & -0.007 & 0.067 \\
\hline
\end{tabular}

\section{Discussion}

The present study showed that Toxoplasma-infected and Toxoplasma-free participants of our crosssectional study differed in three of four factors measured with Political inventory, namely scored higher in Tribalism and lower in Cultural liberalism and Anti-authoritarianism. These results are in line with previous broad research, showing that individuals in parasite affected areas are more likely to be conservative and authoritarian [32]. 
Figure 2. The violin plots show the means and the distribution computed as the kernel probability density for male and female, Toxoplasma-infected and Toxoplasma-free participants of the study.
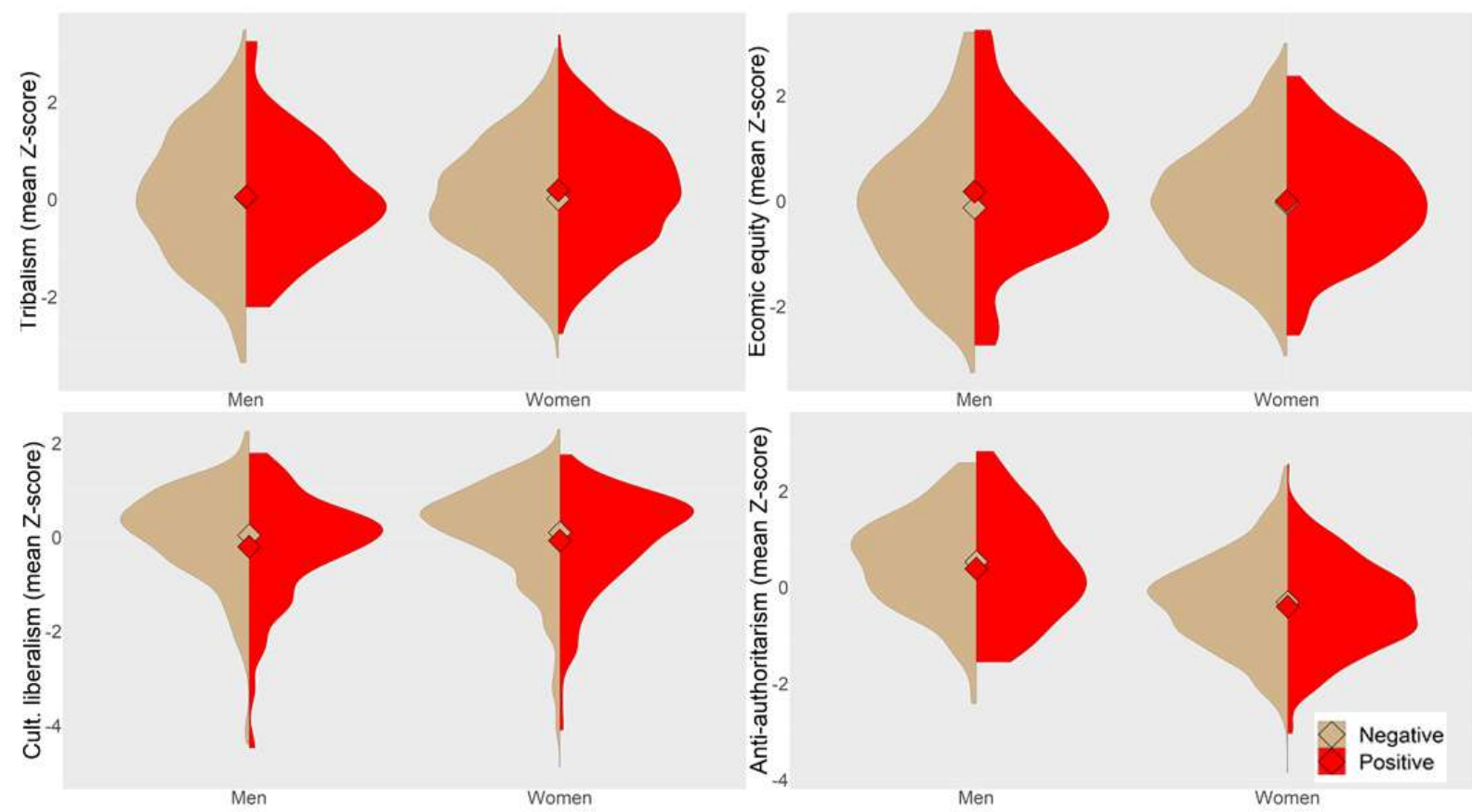

Furthermore, we observed sex differences in the studied factors associated with the Toxoplasma infection. Indeed, Toxoplasma-infected men scored higher in Economic Equity, showing a preference for a more equal and less competitive society, while women infected with toxoplasmosis scored higher in tribalism and lower in cultural liberalism. These as-sociations were not reduced when the effect of worse physical health and mental health were controlled, suggesting that impaired health of infected subjects is not the cause of changes in political beliefs.

The same conclusion was also supported by the fact that the changes go in the same direction in men and women, because stress coping-associated behavioural and personality changes mostly go in different directions in men and women.

It was suggested that [19] these associations might be the results of a mild chronic stress caused by the toxoplasmosis infection instead of the result of the toxoplasmosis it-self. The presence of a chronic stress not only explain the presence of behavioural and political differences with the non-infected control group, but also the presence of sex differences in these behaviour and ideologies as different responses to chronic stress in the two sexes, involving differences in the immune system response and in the coping strategies used. Many of the behavioural changes observed in toxoplasmosis infected people correlate with the function of dopamine in the brain and they may have more broad implications, including political ideologies. In line with our results, a previous study showed that infected subjects scored lower in novelty seeking, a factor that contributes to a conservative and political opinion. Indeed, in our sample the infection was associated with higher tribalism and lower cultural liberalism, specifically in women. While we expected differences in the political ideologies of 
infected men and women, we did not expect a higher score in economic equity in infected men. Typically, men affected with toxoplasmosis showed higher risk propensity and higher entrepreneurial activities [24] more compatible with a competitive type of economy. The association of toxoplasmosis and the preference for an egalitarian economy in men needs to be better explored in future works.

Several studies have found that societies that are more extensively affected by infectious pathogens also exhibit higher levels of conservative political attitudes such as xenophobia and traditionalism [3235]. Similar results have also been found in our study performed on the individual level. The hypothesis that has been proposed is that the attitudes exhibited are connected to pathogen avoidance behaviours aimed at minimising contact with outsiders (intergroup effect) [36] who may be carrying new pathogens as well as the maintenance of social traditions that may serve to help protect against pathogens (intragroup effect) [37], with evidence from a recent cross-national study favouring the intragroup effect [38]. Significantly, however, both the effects - and the intragroup effect in particular seem potentially open to the interpretation that they are generalised responses to stress, rather than to a pathogen [39-42].

While the present study examines differences found in association between a parasitic infection and political values in context of increased stress at individual level, the results cannot be seen as a part of parasite-stress theory $[43,44]$ for the following two main reasons: Parasite-stress theory aims to be the ultimate evolutionary explanation of changes in traits that differ with varied geographical parasite stress levels, yet this study focus-es directly on the difference between actual infected and non-infected subjects in one small region, where the intensity of the parasite stress is mostly constant (and low). Second reason is that it has been shown that primarily non-zoonotic diseases have a relation to human personality and societal values [45]. However, Toxoplasmosis is primarily a zoonotic disease with very specific and limited spread between people - the only intrapersonal route of infection was suggested from male to female or male partners through sexual transmission [46-48].

This being said, there might be a possible connection between the present study and the parasite-stress theory after all. An extensive body of research confirms association be-tween infectious (and in most cases parasitic) diseases and changes in personality profile of animals from molluscs [49] and minnows [50] to migratory birds [51] and mammals [52] including men [53]. There are also well studied associations between personality traits and political views, e.g. [54-57]. While the direction of causality needs to be studied further [58] and while the human-centred field of parasite induced changes in personality traits is regrettably understudied and quite complex [59], we might expect at least some effect of infectious diseases on political attitudes caused by shifts of personality traits. A possibility thus exists, that at least part of the reported difference in political attitudes in countries with different parasitic disease burdens is not caused by parasite-avoidance but results from a significant part of the population being infected with one or multiple pathogens. This hypothesis is supported by studies that linked a change in personality traits with clear connection to political attitudes (e.g., conservatism) with chronic diseases, although not the infectious ones [60,61]. On the other hand, some results suggest stronger prediction of personality traits by historical prevalence of diseases rather than by the cur-rent situation, suggesting parasite-avoidance as a factor with greater importance in personality shifts [62].

Since the available body of literature discussing possible causal relationships be-tween infectious diseases and political beliefs and values is very sparse, this direction of research might provide 
10 / 19 | Le Petit Machiavellian Prince: Effects of latent toxoplasmosis on political beliefs and values

interesting and important insight into the changing political cli-mate in certain countries. Studies focused on a wider range of infectious diseases besides toxoplasmosis and severe debilitating illnesses such as neurocysticercosis or AIDS would be especially valuable.

\section{Limitations}

The main limitation of the present study was the fact that the participants of the study were selfselected. Their subpopulation probably represents a rather altruistic or curious segment of the Czech internet population, rather than a random sample of the Czech internet population. It is not therefore clear to which extent the results can be generalized to the general Czech (or the World) population.

Another limitation of the study is the moderate number of Toxoplasma-infected men (90). Due to the lower number of men, the associations of toxoplasmosis with Cultural liberalism and Antiauthoritarianism were not significant in men, despite being stronger in men than in the more numerous (518) women.

Since this study dealt with the effect of pathogen-caused stress, there is a possible interference of the global COVID-19 pandemics. However, only 6\% of the respondents participated in the period between April 2020 when the first infection in Czechia was observed, and the end of data collection in April 2021.

The associations found in the present study are based on correlations and we cannot infer the direction of causality. It cannot be ruled out that the explanation of the effect is in the opposite direction, that e.g., higher tribalism itself, by an unknown mechanism, in-creases the chance of being infected by Toxoplasma gondii.

Further research is needed to better clarify the extension and the implication of the associations we found between toxoplasmosis infection and political ideologies, and to clarify the role of sex differences. Additionally, further research should focus on the causal direction of the relationships.

\section{Material and Methods}

\subsection{Subjects}

The questionnaire was distributed via the internet as an online Qualtrics survey. Participants were invited to partake in the study using a social media-based snowball meth-od [63]. Potential volunteers, mostly members of the "Lab bunnies" community, an 18,000-member group of Czech and Slovak nationals willing to take part in evolutionary psychology experiments, were invited to participate in an anonymous study about "mystical thinking, superstitions, prejudices, religion and the relation between various environmental factors and health and wellbeing." The online questionnaire was also promoted in various types of electronic and printed media and TV. Toxoplasmosis and political belief were not explicitly mentioned in the information provided to potential participants. Responders were not monetarily compensated for their participation in this study; nevertheless, after finishing the approximately 80-minute questionnaire, they were provided with information about the results of related studies and their own results of several tests that were part of the questionnaire. 
At the beginning of the survey, the participants were given the following information and were asked to provide their informed consent to participate in the study by pressing a special button: "The study is anonymous and obtained data will be used exclusively for scientific purposes. Your cooperation in the project is voluntary and you can terminate it at any time by closing this web page. You can also skip any uncomfortable questions; however, complete data is most valuable. If you agree to participate in the research press the "Next" button". Only the subjects who provided their informed consent (95.2\% of the visitors of the web page) were allowed to participate in the study. Between 27th May 2016 and 24th April 2021, 14,902 responders took part in the study.

All methods were performed in accordance with the relevant guidelines and regulations. The project, including the method of obtaining electronic informed consent to participate in this anonymous study from all participants, was approved by the IRB of the Faculty of Science, Charles University (Komise pro práci s lidmi a lidským materiálem Př́rodovědecké Fakulty Univerzity Karlovy)—No. 2015/07.

\subsection{Questionnaire}

The electronic survey consisted of several parts that concerned various unrelated projects on evolutionary psychology and psychiatry. In the present study, we inspected and analysed only the data from the Political Inventory (see below), Toxoplasma seropositivity. To control for potential confounding variables, the responders were also asked about their sex, age, education (ordinal scale 1-8: 1- elementary, 8- Ph.D.), and the size of the communities where they currently live (ordinal variable urbanization: 0- less than 1000 inhabitants, 1-1-5 thousand inhabitants, 2: 5-50 thousand inhabitants, 3: 50-100 thousand inhabitants, 4: 100-500 thousand inhabitants, 5: more than 500 thousand in-habitants).

In the anamnestic part of the questionnaire, the participants were also asked to respond to a set of questions concerning their physical health and mental health. They were asked how many different prescription drugs they were taking currently, how many different non-prescription drugs they were taking currently ("how many different herbs, food supplements, multivitamins, superfoods, etc. do you currently take per day"), how many times they visited their primary care doctor in past 365 days ("not for prevention"), how many times they used antibiotics in the past 365 days, and how many different medical specialists they visited (not for prevention) in the past 5 years. The physical health problems score was calculated as a mean of Z-scores of the last five variables. The responders were also requested to rate how much they suffer from anxieties, phobias, depression, mania, obsessions, auditory hallucinations, and visual hallucinations, using a 0-100 scale. We also counted the number of diagnosed and the number of undiagnosed mental health disorders that the responders checked on a list of 25 mental health disorders and epilepsy. The mental health problems score was calculated as a mean of Z-scores of these 9 variables.

Political beliefs and values of the responders were measured with the Political Inventory (PI34). This instrument consisted of 34 questions (see English translation in appendix) in randomised order, answers measured agreement on Likert scale (strongly dis-agree, rather disagree, something between, rather agree, strongly agree) to statements. Rather than examining actual partisanship related to established political parties or established ideologies, we assembled the Political Inventory based on contemporary public discourse in the Czech society as a culturally specific questionnaire 
was needed. Selection of topics for PI34 was inspired mainly by 10 Items in the ideological Consistency Scale by PEW based on the using set of questions since 1994 [64] and the 12-item political and social conservatism scale [65].

\subsection{Statistics}

The raw data file contained the records of 14,902 participants, some of them, however, did not complete the final parts of the questionnaire with the political inventory. We filtered out all subjects younger than 18 and older than 90 years. We also filtered out all records with suspicious data, e.g., those from subjects reporting too low $(<130 \mathrm{~cm})$ or high $(>215 \mathrm{~cm})$ body height and too high number of reported diagnosed or undiagnosed mental health disorders $(>10)$. This data set was used for computing physical health problem scores, mental health score (see above), and for factor analyses. In the main analyses, we used the factors (scores) computed with the Maximum likelihood factors extraction method after varimax rotation, however, the results were very robust; a nearly identical structure of factors was obtained with another method of factor extraction and other methods of factor rotation. In fact, all four factors (plus four other factors) were identified even by the principal component analysis.

For analysing the association between toxoplasmosis and political beliefs we used a core data set consisting of 2315 responders who had been tested for toxoplasmosis in the past and were able to provide us with the information about the results of their laboratory test. About 39\% of participants were tested in our laboratory during other scientific studies, 29\% during pregnancy, 22\% because of their health problems, and 10\% for other reasons, e.g., curiosity, blood donation, their partner's pregnancy, etc. Some output variables had asymmetric distribution; therefore, we performed all focal analyses with a partial Kendall test that is not sensitive to such irregularity in data. The correction for multiple tests was performed with the Benjamini-Hochberg procedure with a False Discovery Rate set to 0.1 [66]. Partial Kendall tests were performed in R 3.3.1 [67] using the package ppcor [68]. All other tests, factor analyses, and PCA analyses were performed with the statistical package Statistica v. 10.0.

\section{Conclusions}

Beside worse mental health in Toxoplasma-infected women and worse physical health of Toxoplasmainfected participants of both sexes, our study showed sex-dependent differences in Tribalism, Cultural liberalism, and Anti-authoritarianism between Toxo-plasma-positive and Toxoplasma-negative subjects. Specifically, we have found positive as-sociation of toxoplasmosis and Tribalism in women but not in men, and a positive association of toxoplasmosis and preference for social equity in men but not in women, in both sexes, there were also negative associations with Cultural liberalism and AntiAuthoritarianism. While our results are in agreement with the parasite-stress theory that predicts higher Authoritarianism and Conservatism in areas with higher prevalence of parasitic diseases, the results cannot be interpreted simply in the framework of the theory as a result of behavioural immunity (i.e., parasite avoidance). Rather, the direct effect of long-term mild stress caused by an inflammatory reaction to the presence of a parasite may be at play, shifting hosts' personalities and thus also their political attitudes. Considering the substantial lack of literature discussing effects of mild infectious diseases on personality traits of infected individuals as well as effects of being infected by a parasite on political beliefs and values, further research should be encouraged. 
13 / 19 Le Petit Machiavellian Prince: Effects of latent toxoplasmosis on political beliefs and values

Author contribution: Conceptualization RK, LP, JF; methodology RK, LP, SB, KTK, JF; data curation JF; statistical analysis JF; writing - original draft and reviewing and editing RK, LP, SB, KTK, JF. All authors have read and agreed to the published version of the manuscript. Authors' ORCIDs:

- Robin Kopecky https://orcid.org/0000-0002-7140-4649

- Lenka Př́platová https://orcid.org/0000-0002-2860-3853

- Silvia Boschetti https://orcid.org/0000-0002-8048-4062

- Konrad Talmont-Kaminski https://orcid.org/0000-0002-7144-4384

- Jaroslav Flegr https://orcid.org/0000-0002-0822-0126

Funding: This research was funded by Czech Science Foundation, grant number 21-31059S

Institutional Review Board Statement: This study was approved by the IRB of the Faculty of Science, Charles University (Komise pro práci s lidmi a lidským materiálem Př́rodovědecké Fakulty Univerzity Karlovy)—No. 2015/07

Informed Consent Statement: Informed consent was obtained from all subjects involved in the study.

Data Availability Statement: Dataset available on Figshare.com https://figshare.com/s/fb78539b38e11db6f73f

Conflict of Interest: The authors declare no conflict of interest.

\section{Appendix A}

Political beliefs and values inventory PI34

1. The gap between high and low incomes should be reduced.

2. It is acceptable for a same sex couple to live together.

3. Everyone should have the right to publicly protest against or for something.

4. Because we cannot trust corporations that they will respect environmental protection voluntarily, it is necessary to regulate them by law.

5. What is good for big corporations is in consequence good for society.

6. Differences in wealth and social status should be as small among people as possible.

7. If I were married, I wouldn't mind my partner watching pornography alone.

8. My government should value the lives of its citizens more than the lives of foreigners.

9. Minorities of different nationalities are a threat for our culture.

10. People are divided more by their socioeconomic status than by their nationality.

11. People with high incomes are paying overly high taxes.

12. It should be forbidden to publicly insult someone's religion.

13. Growing marihuana for one's own use should not be criminalized.

14. People should have the right to end their life with the help of a physician if they ask for it.

15. Parents should be allowed to physically punish their children.

16. There are no savages, barbarians or primitive cultures in the world, just different kinds of culture.

17. I wish that nations and state borders cease to exist, so we become members of one big group. 
14 / 19 Le Petit Machiavellian Prince: Effects of latent toxoplasmosis on political beliefs and values

18. The first generation and the majority of the second generation of immigrants will not completely integrate in their new country.

19. For those who are able but not willing to work, there should be no social benefits.

20. It should be held true: "From each according to their ability, to each according to their needs."

21. Mothers of children can have their own career; however, their primary role is to take good care of children and the household.

22. Free speech is more important than the possibility of someone feeling deeply offend-ed.

23. If a mother's life is not endangered, abortion should be prohibited by law.

24. It is necessary to teach children to respect authorities and superiors.

25. I am proud of the history of my country.

26. A society that is poor but equal is better than a rich society that is stratified in income and wealth.

27. The freer the market the freer the society.

28. It is acceptable that parents prefer their children to be educated at home instead of sending them to school.

29. The state shouldn't have the right to censor the internet.

30. It should be held true: "An eye for an eye, a tooth for a tooth."

31. I would sacrifice my life for my nation!

32. Capital punishment should be re-introduced for exceptionally serious crimes.

33. Adults with clean criminal records should have a right to own a firearm.

34. Foreigners who commit a criminal offense in our country should be deported to their country of origin.

\section{References}

1. Tenter, A.M.; Heckeroth, A.R.; Weiss, L.M. Toxoplasma gondii: from animals to humans. Int. J. Parasitol. 2000, 30, 1217-1258, doi:10.1016/S0020-7519(00)00124-7.

2. $\quad$ Flegr, J.; Prandota, J.; Sovičková, M.; Israili, Z.H. Toxoplasmosis - A Global Threat. Correlation of Latent Toxoplasmosis with Specific Disease Burden in a Set of 88 Countries. PLoS One 2014, 9, e90203, doi:10.1371/journal.pone.0090203.

3. Flegr, J.; Escudero, D.Q. Impaired health status and increased incidence of diseases in Toxoplasma-seropositive subjects-an explorative cross-sectional study. 2016, doi:10.1017/S0031182016001785.

4. Lindová, J.; Příplatová, L.; Flegr, J. Higher Extraversion and Lower Conscientiousness in Humans Infected with Toxoplasma. Eur. J. Pers. 2012, 26, 285-291, doi:10.1002/per.838.

5. Khademvatan, S.; Khajeddin, N.; Saki, J.; Izadi-Mazidi, S. Effect of toxoplasmosis on personality profiles of Iranian men and women. S. Afr. J. Sci. 2013, 109, 1-4, doi:10.1590/sajs.2013/0017.

6. Flegr, J. Influence of latent Toxoplasma infection on human personality, physiology and morphology: pros and cons of the Toxoplasma-human model in studying the manipulation hypothesis. J. Exp. Biol. 2013, 216, 127-133, doi:10.1242/JEB.073635. 
7. Houdek, P. Puppet Master: Possible Influence of the Parasite Toxoplasma Gondii on Managers and Employees. Acad. Manag. Perspect. 2017, 31, 63-81, doi:10.5465/amp.2015.0163.

8. Fekadu, A.; Shibre, T.; Cleare, A.J. Toxoplasmosis as a cause for behaviour disorders overview of evidence and mechanisms. Folia Parasitol. (Praha). 2010, 57, 105-113, doi:10.14411/fp.2010.013.

9. Webster, J.P. The effect of Toxoplasma gondii on animal behavior: Playing cat and mouse. Schizophr. Bull. 2007, 33, 752-756, doi:10.1093/schbul/sbl073.

10. Lindova, J.; Kubena, A.A.; Sturcova, H.; Krivohlava, R.; Novotna, M.; Rubesova, A.; Havlicek, J.; Kodym, P.; Flegr, J. Pattern of money allocation in experimental games supports the stress hypothesis of gender differences in Toxoplasma gondii-induced behavioural changes. Folia Parasitol. (Praha). 2010, 57, 136-142, doi:10.14411/fp.2010.017.

11. Tedford, E.; McConkey, G. Neurophysiological changes induced by chronic Toxoplasma gondii infection. Pathogens 2017, 6, 19, doi:10.3390/pathogens6020019.

12. Martynowicz, J.; Augusto, L.; Wek, R.C.; Boehm, S.L.; Sullivan, W.J. Guanabenz Reverses a Key Behavioral Change Caused by Latent Toxoplasmosis in Mice by Reducing Neuroinflammation. MBio 2019, 10, doi:10.1128/mBio.00381-19.

13. Lindová, J.; Novotná, M.; Havlíček, J.; Jozífková, E.; Skallová, A.; Kolbeková, P.; Hodný, Z.; Kodym, P.; Flegr, J. Gender differences in behavioural changes induced by latent toxoplasmosis. Int. J. Parasitol. 2006, 36, 1485-1492, doi:10.1016/j.ijpara.2006.07.008.

14. Tamres, L.K.; Janicki, D.; Helgeson, V.S. Sex Differences in Coping Behavior: A MetaAnalytic Review and an Examination of Relative Coping: http://dx.doi.org/10.1207/S15327957PSPR0601_1 2016, 6, 2-30, doi:10.1207/S15327957PSPR0601_1.

15. Matud, M.P. Gender differences in stress and coping styles. Pers. Individ. Dif. 2004, 37, 1401-1415, doi:10.1016/J.PAID.2004.01.010.

16. Bernardi, S.; Toffoli, B.; Tonon, F.; Francica, M.; Campagnolo, E.; Ferretti, T.; Comar, S.; Giudici, F.; Stenner, E.; Fabris, B. Sex Differences in Proatherogenic Cytokine Levels. Int. J. Mol. Sci. 2020, Vol. 21, Page 3861 2020, 21, 3861, doi:10.3390/IJMS21113861.

17. Lefèvre, N.; Corazza, F.; Duchateau, J.; Desir, J.; Casimir, G. Sex differences in inflammatory cytokines and CD99 expression following in vitro lipopolysaccharide stimulation. Shock 2012, 38, 37-42, doi:10.1097/SHK.0B013E3182571E46.

18. Felger, J.C.; Miller, A.H. Cytokine effects on the basal ganglia and dopamine function: The subcortical source of inflammatory malaise. Front. Neuroendocrinol. 2012, 33, 315-327, doi:10.1016/J.YFRNE.2012.09.003.

19. Kamerkar, S.; Davis, P.H. Toxoplasma on the brain: Understanding host-pathogen interactions in chronic CNS infection. J. Parasitol. Res. 2012, 2012, doi:10.1155/2012/589295.

20. Skallová, A.; Kodym, P.; Frynta, D.; Flegr, J. The role of dopamine in Toxoplasma-induced behavioural alterations in mice: An ethological and ethopharmacological study.

Parasitology 2006, 133, 525-535, doi:10.1017/S0031182006000886. 
21. Flegr, J. Effects of Toxoplasma on human behavior. Schizophr. Bull. 2007, 33, 757-760, doi:10.1093/schbul/sbl074.

22. Flegr, J.; Preiss, M.; Klose, J.; Havlíček, J.; Vitáková, M.; Kodym, P. Decreased level of psychobiological factor novelty seeking and lower intelligence in men latently infected with the protozoan parasite Toxoplasma gondii Dopamine, a missing link between schizophrenia and toxoplasmosis? Biol. Psychol. 2003, 63, 253-268, doi:10.1016/S0301-0511(03)00075-9.

23. Skallová, A.; Novotná, M.; Kolbeková, P.; Gašová, Z.; Veselý, V.; Sechovská, M.; Flegr, J. Decreased level of novelty seeking in blood donors infected with Toxoplasma. Neuroendocrinol. Lett. 2005, 26, 480-486.

24. Johnson, S.K.; Fitza, M.A.; Lerner, D.A.; Calhoun, D.M.; Beldon, M.A.; Chan, E.T.; Johnson, P.T.J. Risky business: linking Toxoplasma gondii infection and entrepreneurship behaviours across individuals and countries. Proc. R. Soc. B Biol. Sci. 2018, 285, doi:10.1098/RSPB.2018.0822.

25. Flegr, J.; Havlícek, J.; Kodym, P.; Malý, M.; Smahel, Z. Increased risk of traffic accidents in subjects with latent toxoplasmosis: A retrospective case-control study. BMC Infect. Dis. 2002, 2, 11, doi:10.1186/1471-2334-2-11.

26. Kocazeybek, B.; Oner, Y.A.; Turksoy, R.; Babur, C.; Cakan, H.; Sahip, N.; Unal, A.; Ozaslan, A.; Kilic, S.; Saribas, S.; et al. Higher prevalence of toxoplasmosis in victims of traffic accidents suggest increased risk of traffic accident in Toxoplasma-infected inhabitants of Istanbul and its suburbs. Forensic Sci. Int. 2009, 187, 103-108, doi:10.1016/J.FORSCIINT.2009.03.007.

27. Cook, T.B.; Brenner, L.A.; Cloninger, C.R.; Langenberg, P.; Igbide, A.; Giegling, I.; Hartmann, A.M.; Konte, B.; Friedl, M.; Brundin, L.; et al. "Latent" infection with Toxoplasma gondii: Association with trait aggression and impulsivity in healthy adults. J. Psychiatr. Res. 2015, 60, 87-94, doi:10.1016/j.jpsychires.2014.09.019.

28. Mathai, A.J.; Lowry, C.A.; Cook, T.B.; Brenner, L.A.; Brundin, L.; Groer, M.W.; Peng, X.; Giegling, I.; Hartmann, A.M.; Konte, B.; et al. Reciprocal moderation by Toxoplasma gondii seropositivity and blood phenylalanine - tyrosine ratio of their associations with trait aggression. Pteridines 2016, 27, 77-85, doi:10.1515/PTERID-2016-0006.

29. Postolache, T.T.; Wadhawan, A.; Rujescu, D.; Hoisington, A.J.; Dagdag, A.; Baca-Garcia, E.; Lowry, C.A.; Okusaga, O.O.; Brenner, L.A. Toxoplasma gondii, Suicidal Behavior, and Intermediate Phenotypes for Suicidal Behavior. Front. Psychiatry 2021, 0, 806, doi:10.3389/FPSYT.2021.665682.

30. Meehan, R.A.; Brush, J.A. An overview of AIDS dementia complex: http://dx.doi.org/10.1177/153331750101600411 2016, 16, 225-229, doi:10.1177/153331750101600411.

31. El-Kady, A.M.; Allemailem, K.S.; Almatroudi, A.; Abler, B.; Elsayed, M. Psychiatric Disorders of Neurocysticercosis: Narrative Review. Neuropsychiatr. Dis. Treat. 2021, 17, 1599, doi:10.2147/NDT.S306585.

32. Murray, D.R.; Schaller, M.; Suedfeld, P. Pathogens and Politics: Further Evidence That Parasite Prevalence Predicts Authoritarianism. PLoS One 2013, 8, e62275, doi:10.1371/JOURNAL.PONE.0062275. 
33. Thornhill, R.; Fincher, C.L.; Aran, D. Parasites, democratization, and the liberalization of values across contemporary countries. Biol. Rev. 2009, 84, 113-131, doi:10.1111/J.1469-185X.2008.00062.X.

34. Nikolaev, B.; Salahodjaev, R. Historical Prevalence of Infectious Diseases, Cultural Values, and the Origins of Economic Institutions. Kyklos 2017, 70, 97-128, doi:10.1111/KYKL.12132.

35. Bennett, D.L.; Nikolaev, B. Historical Disease Prevalence, Cultural Values, and Global Innovation: https://doi.org/10.1177/1042258720914506 2020, 45, 145-174, doi:10.1177/1042258720914506.

36. Aarøe, L.; Petersen, M.B.; Arceneaux, K. The Behavioral Immune System Shapes Political Intuitions: Why and How Individual Differences in Disgust Sensitivity Underlie Opposition to Immigration. Am. Polit. Sci. Rev. 2017, 111, 277-294, doi:10.1017/S0003055416000770.

37. Fincher, C.L.; Thornhill, R. Parasite-stress promotes in-group assortative sociality: The cases of strong family ties and heightened religiosity. Behav. Brain Sci. 2012, 35, 61-79, doi:10.1017/S0140525X11000021.

38. Tybur, J.M.; Inbar, Y.; Aarøe, L.; Barclay, P.; Barlow, F.K.; Barra, M. de; Becker, D.V.; Borovoi, L.; Choi, I.; Choi, J.A.; et al. Parasite stress and pathogen avoidance relate to distinct dimensions of political ideology across 30 nations. Proc. Natl. Acad. Sci. 2016, 113, 12408-12413, doi:10.1073/PNAS.1607398113.

39. Hruschka, D.J.; Henrich, J. Institutions, Parasites and the Persistence of In-group Preferences. PLoS One 2013, 8, e63642, doi:10.1371/JOURNAL.PONE.0063642.

40. Brown, G.D.A.; Fincher, C.L.; Walasek, L. Personality, Parasites, Political Attitudes, and Cooperation: A Model of How Infection Prevalence Influences Openness and Social Group Formation. Top. Cogn. Sci. 2016, 8, 98-117, doi:10.1111/TOPS.12175.

41. Currie, T.E.; MacE, R. Analyses do not support the parasite-stress theory of human sociality. Behav. Brain Sci. 2012, 35, 83-85, doi:10.1017/S0140525X11000963.

42. MZ, M. Testing the parasite-stress theory of sociality based on the circular model of human values: A multilevel analysis approach. Pers. Individ. Dif. 2020, 168, 110277110277, doi:10.1016/J.PAID.2020.110277.

43. Fincher, C.L.; Thornhill, R.; Murray, D.R.; Schaller, M. Pathogen prevalence predicts human cross-cultural variability in individualism/collectivism. Proc. R. Soc. B Biol. Sci. 2008, 275, 1279-1285, doi:10.1098/RSPB.2008.0094.

44. Thornhill, R.; Fincher, C.L. The parasite-stress theory of sociality, the behavioral immune system, and human social and cognitive uniqueness. Evol. Behav. Sci. 2014, 8, 257-264, doi:10.1037/EBS0000020.

45. Thornhill, R.; Fincher, C.L.; Murray, D.R.; Schaller, M. Zoonotic and Non-Zoonotic Diseases in Relation to Human Personality and Societal Values: Support for the ParasiteStress Model: http://dx.doi.org/10.1177/147470491000800201 2010, 8, 151-169, doi:10.1177/147470491000800201.

46. Flegr, J.; Klapilová, K.; Kaňková, S. Toxoplasmosis can be a sexually transmitted infection with serious clinical consequences. Not all routes of infection are created equal. Med. Hypotheses 2014, 83, 286-289, doi:10.1016/J.MEHY.2014.05.019. 
47. Kaňková; Hlaváčová, J.; Flegr, J. Oral sex: A new, and possibly the most dangerous, route of toxoplasmosis transmission. Med. Hypotheses 2020, 141, 109725, doi:10.1016/J.MEHY.2020.109725.

48. Hlaváčová, J.; Flegr, J.; Řežábek, K.; Calda, P.; Kaňková, Š. Male-to-Female Presumed Transmission of Toxoplasmosis Between Sexual Partners. Am. J. Epidemiol. 2021, 190, 386-392, doi:10.1093/AJE/KWAA198.

49. Seaman, B.; Briffa, M. Parasites and personality in periwinkles (Littorina littorea): Infection status is associated with mean-level boldness but not repeatability. Behav. Processes 2015, 115, 132-134, doi:10.1016/J.BEPROC.2015.03.014.

50. Kekäläinen, J.; Lai, Y.-T.; Vainikka, A.; Sirkka, I.; Kortet, R. Do brain parasites alter host personality? — Experimental study in minnows. Behav. Ecol. Sociobiol. 2013682 2013, 68, 197-204, doi:10.1007/S00265-013-1634-2.

51. Marinov, M.P.; Marchetti, C.; Dimitrov, D.; Ilieva, M.; Zehtindjiev, P. Mixed haemosporidian infections are associated with higher fearfulness in Yellow Wagtail (Motacilla flava). https://doi.org/10.1139/cjz-2016-0121 2017, 95, 405-410, doi:10.1139/CJZ-2016-0121.

52. Boyer, N.; Réale, D.; Marmet, J.; Pisanu, B.; Chapuis, J.-L. Personality, space use and tick load in an introduced population of Siberian chipmunks Tamias sibiricus. J. Anim. Ecol. 2010, 79, 538-547, doi:10.1111/J.1365-2656.2010.01659.X.

53. Webster, J.P. Rats, cats, people and parasites: The impact of latent toxoplasmosis on behaviour. Microbes Infect. 2001, 3, 1037-1045, doi:10.1016/S1286-4579(01)01459-9.

54. Verhulst, B.; Hatemi, P.K.; Martin, N.G. The nature of the relationship between personality traits and political attitudes. Pers. Individ. Dif. 2010, 49, 306-316, doi:10.1016/J.PAID.2009.11.013.

55. Wang, C.H. Personality traits, political attitudes and vote choice: Evidence from the United States. Elect. Stud. 2016, 44, 26-34, doi:10.1016/J.ELECTSTUD.2016.07.004.

56. Furnham, A.; Fenton-O'Creevy, M. Personality and political orientation. Pers. Individ. Dif. 2018, 129, 88-91, doi:10.1016/J.PAID.2018.03.020.

57. Harell, A.; Hinckley, R.; Mansell, J. Valuing Liberty or Equality? Empathetic Personality and Political Intolerance of Harmful Speech. Front. Polit. Sci. 2021, 0, 64, doi:10.3389/FPOS.2021.663858.

58. Bakker, B.N.; Lelkes, Y.; Malka, A. Reconsidering the Link Between Self-Reported Personality Traits and Political Preferences. Am. Polit. Sci. Rev. 2021, 1-17, doi:10.1017/S0003055421000605.

59. Friedman, H.S. The multiple linkages of personality and disease. Brain. Behav. Immun. 2008, 22, 668-675, doi:10.1016/J.BBI.2007.09.004.

60. Mendelsohn, G.A.; Dakof, G.A.; Skaff, M. Personality Change in Parkinson's Disease Patients: Chronic Disease and Aging. J. Pers. 1995, 63, 233-257, doi:10.1111/J.14676494.1995.TB00809.X.

61. Sutin, A.R.; Zonderman, A.B.; Ferrucci, L.; Terracciano, A. Personality Traits and Chronic Disease: Implications for Adult Personality Development. Journals Gerontol. Ser. B 2013, 68, 912-920, doi:10.1093/GERONB/GBT036. 
19 / 19 Le Petit Machiavellian Prince: Effects of latent toxoplasmosis on political beliefs and values

62. Schaller, M.; Murray, D.R. Pathogens, Personality, and Culture: Disease Prevalence Predicts Worldwide Variability in Sociosexuality, Extraversion, and Openness to Experience. J. Pers. Soc. Psychol. 2008, 95, 212-221, doi:10.1037/0022-3514.95.1.212.

63. Kankova, S.; Flegr, J.; Calda, P. The influence of latent toxoplasmosis on women's reproductive function: four cross-sectional studies. Folia Parasitol. (Praha). 2015, 62.

64. Appendix A: The Ideological Consistency Scale | Pew Research Center Available online: https://www.pewresearch.org/politics/2014/06/12/appendix-a-the-ideologicalconsistency-scale/ (accessed on Sep 30, 2021).

65. Everett, J.A.C. The 12 Item Social and Economic Conservatism Scale (SECS). PLoS One 2013, 8, e82131, doi:10.1371/JOURNAL.PONE.0082131.

66. Benjamini, Y.; Hochberg, Y. Controlling the False Discovery Rate: A Practical and Powerful Approach to Multiple Testing. J. R. Stat. Soc. Ser. B 1995, 57, 289-300, doi:10.1111/J.2517-6161.1995.TB02031.X.

67. R Core Team R: A Language and Environment for Statistical Computing; R Foundation for Statistical Computing: Vienna, Austria, 2018.

68. Kim, S. ppcor: An R Package for a Fast Calculation to Semi-partial Correlation Coefficients. Commun. Stat. Appl. methods 2015, 22, 665, doi:10.5351/CSAM.2015.22.6.665. 